\title{
Above the Veil: Revisiting the Classicism of W. E. B. Du Bois
}

\author{
Harriet Fertik $^{1} \cdot$ Mathias Hanses ${ }^{2}$
}

Published online: 17 July 2018

(C) Springer Science+Business Media B.V., part of Springer Nature 2018

\begin{abstract}
Studies of W. E. B. Du Bois typically emphasize his shift from an elitist devotion to European classics to a more radical promotion of African culture. These essays move beyond this simple dichotomy. We aim to demonstrate that throughout his life, Du Bois used classical ideas to challenge white Americans' exclusive claims to power, even as he recognized and critiqued the role of Classics in sustaining racist hierarchies and institutions. Rather than focus exclusively on explicit citations of Greece and Rome in Du Bois's writing, we use Henry Louis Gates, Jr.'s model of Signifyin(g) and Lorna Hardwick's conception of 'fuzzy connections' to trace and interrogate Du Bois's elusive engagement with Classics. We provide detailed studies of three works: The Souls of Black Folk (1903), The Star of Ethiopia (1910s) and 'Of the Ruling of Men' (1920). The concluding essay situates Du Bois's classicism in the wider context of African American literature and at the intersection of debates on education, humanism, and race in America. Throughout these papers, we examine Du Bois's understanding of what is at stake for those who present themselves as the inheritors and interpreters of antiquity. By putting Du Bois back at the centre of ongoing scholarly conversations on black classicism, we hope to show that his inventive and political approach to the past provides a valuable model for reception studies today.
\end{abstract}

In the spring of 1919, in the immediate aftermath of World War I, W. E. B. Du Bois (1868-1963) toured the battlefields of France. He was then the editor of The Crisis,

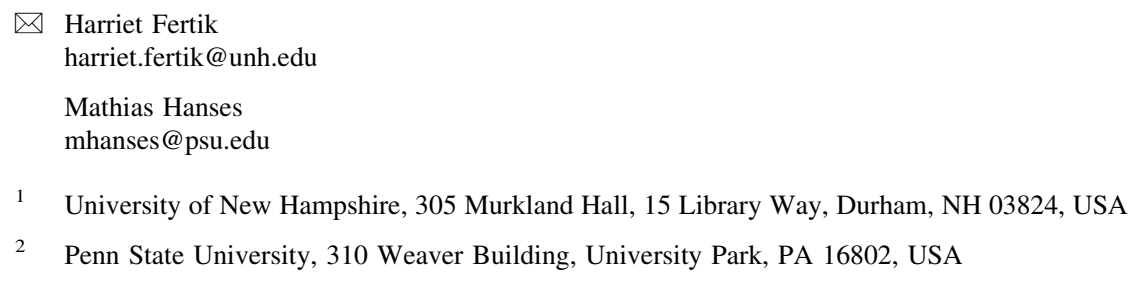


the NAACP's flagship publication, and the letters he sent back to New York attest to his shock at the havoc wreaked on what he called 'The Wounded World'. At the same time, his visit to France was also a cause for optimism. In particular, Du Bois mingled with like-minded thinkers and activists at a Pan-African Congress in Paris, and concluded that nowhere was race prejudice less prevalent than in France and other Romance nations. ${ }^{1}$ For that reason,

Every Negro should speak French. Large numbers should speak Spanish and Portuguese. Let these languages immediately begin to displace Latin, Greek and Hebrew in our schools. The ancient tongues have their proud place in human discipline and should never yield to 'agriculture' and pseudo-science, but they must yield to modern tongues taught modern-wise. ${ }^{2}$

This call to phase out ancient languages reflects a significant change in Du Bois's thought on education: he had built his reputation in large part on his plainspoken demand that disenfranchised African Americans be provided with access to traditional college training in the liberal arts, and most notably in the Classics. Scholars writing Du Bois's intellectual biography typically emphasize his shift during the early twentieth century from elitist devotion to the canonical texts of European literature, to commitment to new disciplines and fields of research (such as sociology and economics) and then to a more radical promotion of African culture. ${ }^{3}$ But while this account is certainly accurate in broad terms, one of Du Bois's most energetic defences of the values instilled by a classical education dates to 1924. Speaking at Fisk University in the year of his daughter's graduation, he delivered an address entitled Diuturni Silenti. This speech begins with the opening words of Pro Marcello, and presents Du Bois as a modern-day Cicero endorsing 'the principle ancient as Greece and older: "Know Thyself.", 4

One of our objectives in this collection of essays, then, is to move beyond easy dichotomies. We aim to demonstrate that throughout his life, Du Bois used classical ideas to challenge racism both in the U.S. and abroad. At the same time, he could be critical of the Greek and Roman tradition and its role in sustaining racist hierarchies and institutions, even when his calls to study the Classics were at their most emphatic.

An additional and equally important imperative is to bring the study of Du Bois's classicism up to the standard of recent methodological advances both in the wider field of reception studies and more specifically in black classicism. We now have many studies of black writers, men and women, who engaged with the Classics in creative and meaningful ways; the most insightful theoretical discussions seek to define, in particular, the place of these writers in varied local and global intellectual

\footnotetext{
1 D. L. Lewis, W. E. B. Du Bois: Biography of a Race, 1868-1919, New York, 1993, pp. 561-80.

2 W. E. B. Du Bois, 'Easter 1919', The Crisis, 17, 1919, pp. 267-70 (269).

3 E.g., D. P. Alridge, The Educational Thought of W. E. B. Du Bois: An Intellectual History, New York, 2008.

4 W. E. B. Du Bois, 'Diuturni Silenti', in The Education of Black People: Ten Critiques, 1906-1960, ed. H. Aptheker, New York, 1973, pp. 41-60 (47).
} 
traditions. ${ }^{5}$ Much recent research has also mapped the scholarship and activism of black academics who specialized in the Classics, particularly in the post-Civil War United States. ${ }^{6}$ Du Bois belongs in both categories. Yet perhaps because he may be the most famous black intellectual ever to have engaged with Greco-Roman antiquity, scholars moved on from him before these key developments in the field occurred. With the notable exception of Eric Ashley Hairston's The Ebony Column, ${ }^{7}$ studies of Du Bois's classicism either pre-date the relevant transformative works on Africana receptions (like Carrie Cowherd's seminal discussion of classical allusion in The Souls of Black Folk, from 2003), ${ }^{8}$ or do not take them into account. ${ }^{9}$ Since Du Bois's works demand the same kind of nuanced analysis that characterizes recent scholarship in black classicism, our essays aim to fill this gap.

Accordingly, we here revisit and expand past explorations of Du Bois's engagement with literary, historical, and mythological touchstones of Greek and Roman antiquity. Du Bois began his studies of Greek and Latin in collegepreparation classes in his hometown of Great Barrington, Massachusetts. He continued to immerse himself in the Classics, certainly at Fisk University in Nashville, Tennessee (1885-1888), and likely also at Harvard (1890-1892) and during a stay at the University of Berlin (1892-1894). Most notably, Du Bois - the first African American to earn a PhD from Harvard (1895) - worked as a professor of Greek and Latin literature at Wilberforce University in Ohio from 1894 to 1896 (a job he reportedly despised). After 1896, he moved on first to the University of Pennsylvania, then to a chair in history and economics at Atlanta University and eventually to a prominent career in civil rights activism. We know from his papers and educational records that he took classes in Greek and Latin composition and that he definitely read the following works in their original language: Book One of Thucydides; selections from Greek drama; Plato's Phaedo; extensive selections from Xenophon's Anabasis and the Memorabilia; Books One through Four of

\footnotetext{
5 See esp. P. D. Rankine, Ulysses in Black: Ralph Ellison, Classicism, and African American Literature, Madison, WI, 2006; B. Goff and M. Simpson, Crossroads in the Black Aegean: Oedipus, Antigone, and Dramas of the African Diaspora, Oxford, 2007; E. Greenwood, Afro-Greeks: Dialogues between Anglophone Caribbean Literature and Classics in the Twentieth Century, New York, 2010; African Athena: New Agendas, ed. D. Orrells, G. K. Bhambra, and T. Roynon, Oxford, 2011; J. McConnell, Black Odysseys: The Homeric Odyssey in the African Diaspora since 1939, Oxford, 2013; T. Roynon, Toni Morrison and the Classical Tradition: Transforming American Culture, Oxford, 2013; M. Malamud, African Americans and the Classics: Antiquity, Abolition, and Activism, London, 2016. For the Black Atlantic as a site of interaction between a global diaspora of black writers and their diverse cultural environs, see P. Gilroy, The Black Atlantic: Modernity and Double Consciousness, Cambridge, MA, 1993.

${ }^{6}$ See esp. The Autobiography of William Sanders Scarborough: An American Journey from Slavery to Scholarship, ed. M. V. Ronnick, Detroit, 2005 and The Works of William Sanders Scarborough: Black Classicist and Race Leader, ed. M. V. Ronnick, New York, 2006. For an overview of the scholarship in this and the previous note, see E. Greenwood, 'Re-rooting the Classical Tradition: New Directions in Black Classicism', Classical Receptions Journal, 1, 2009, pp. 87-103.

7 E. A. Hairston, The Ebony Column: Classics, Civilization, and the African American Reclamation of the West, Knoxville, TN, 2013.

${ }^{8}$ C. Cowherd, 'The Wings of Atalanta: Classical Influences in The Souls of Black Folk', in The Souls of Black Folk: One Hundred Years Later, ed. D. Hubbard, Columbia, MO, 2003, pp. 284-97.

9 E.g., W. W. Cook and J. Tatum, African American Writers and Classical Tradition, Chicago, 2010.
} 
Caesar's Gallic Wars; Cicero's Orations against Catiline, Pro Archia Poeta and half of Pro Marcello; Virgil's Eclogues and the first half of the Aeneid; Horace's Ars Poetica, plus selections from the Odes, Epodes, Satires, and Epistles; Livy, Book Twenty-One; Tacitus's Agricola; and parts of the works of Augustine. It is also clear that he read the Iliad, Odyssey, and many Greek tragedies, at least in translation, and that he was familiar with accounts of Africa by ancient poets and historians (Hesiod, Herodotus, Diodorus Siculus, Strabo, Pliny the Elder, and Dio). ${ }^{10}$

Du Bois's classical training is particularly apparent in one of the most famous passages from The Souls of Black Folk (1903). Here, Du Bois declares,

I sit with Shakespeare, and he winces not. Across the color line I move arm in arm with Balzac and Dumas, where smiling men and welcoming women glide in gilded halls. From out of the caves of evening that swing between the strong-limbed Earth and the tracery of stars, I summon Aristotle and Aurelius and what soul I will, and they come all graciously with no scorn nor condescension. So, wed with Truth, I dwell above the veil. Is this the life you grudge us, O knightly America? Is this the life you long to change into the dull red hideousness of Georgia? Are you so afraid lest peering from this high Pisgah, between Philistine and Amalekite, we sight the Promised Land? ${ }^{11}$

In the above passage, which repeatedly appears in these essays, Du Bois contemplates the long chain of successive authors across many centuries that connects him - via Shakespeare, Balzac, and Dumas; Aurelius and Augustine - to the earliest authors and thinkers of the classical and Judeo-Christian traditions. His imagined encounters with these figures raise three central questions.

First, what counts as classical reception in Du Bois's work? Sometimes we find allusions to specific authors, such as (in this passage) Aristotle and Aurelius, or (as we discuss in the first two essays in this collection) Cicero and Ovid, but Du Bois almost never explains the point of these allusions. Instead, they stand as invitations to his readers to make sense of the relationship between a classical text and Du Bois's own. Even more frequently, Du Bois does not quote a specific passage or name an author at all, but rather gestures to metaphors from Platonic philosophy (the third essay), to distinctive tropes of Aristotelian political thought (the fifth essay) or to the wider cultural landscape of the ancient Mediterranean (the fourth esssay). Nevertheless, we must examine these intertexts between Du Bois's corpus and Greek and Roman literature, even when his knowledge of an ancient text is in doubt. $^{12}$ Lorna Hardwick has described these relationships between modern and

\footnotetext{
${ }^{10}$ For Du Bois's classical training before Harvard, see W. E. B. Du Bois, Against Racism: Unpublished Essays, Papers, Addresses, 1887-1961, ed. H. Aptheker, Amherst, MA, 1985, p. 6. For further details on his life and education, see F. L. Broderick, 'The Academic Training of W. E. B. Du Bois', The Journal of Negro Education, 27, 1958, pp. 10-16; Lewis, Biography of a Race (n. 1 above); and D. L. Lewis, W. E. B. Du Bois: The Fight for Equality and the American Century, 1919-1963, New York, 2000. Du Bois's Black Folk, Then and Now, Millwood, NY, 1939 includes citations from - and attests to his careful reading of - ancient texts on Africa later in his career.

11 W. E. B. Du Bois, The Souls of Black Folk, ed. H. L. Gates Jr. and T. H. Oliver, New York, 1999, pp. 73-4.

12 S. Hinds, Allusion and Intertext: Dynamics of Appropriation in Roman Poetry, Cambridge, 1998, pp. 17-59 is the most influential treatment of this approach to intertextuality in classical studies.
} 
classical works as 'fuzzy connections': the challenge she identifies is 'how to "connect" receptions that are part of different traditions and do not seem to talk directly to one another ... it may be the writer or reader who is the connector, bringing the classical text into a relationship with others on the basis of the connector's own sensibilities and horizons'. ${ }^{13}$ These 'fuzzy connections' require careful argument to trace the conversation between different texts and thus to establish and define the ways in which they 'talk to one another'. In the following essays, we accordingly confront 'questions about how the presence of the ancient text, or of an impression of it, is communicated and about whether and how "recognitions" are triggered in the minds of the receivers'. ${ }^{14}$ Through our readings, we model how Du Bois's work triggers these 'recognitions' of Greek and Roman antiquity.

A second question that the passage from Souls raises regards the stakes of classical reception in Du Bois's work: what does the classical past mean for Du Bois, and why does he engage with it? Du Bois describes literary texts as companions and friends who treat him 'with no scorn nor condescension' and who allow him to 'dwell above the veil' that excludes African Americans from the polity. In other words, Du Bois's relationship with texts allows him to assert his equality with his fellow citizens. In The Signifying Monkey, Henry Louis Gates, Jr. discusses a related trope of literacy in eighteenth-century slave narratives, in which former slaves dwell on their encounters with books and the act of reading. This trope points to the idea that 'true freedom, in the life of the slave, turns upon the mastery of Western letters or, more properly, upon the mastery inherent in the communion of the subject with the logos ... in literacy was to be found the sole sign of difference that separated chattel property from human being'. ${ }^{15}$ Prompted by the work of Patrice Rankine in the conclusion, the authors in our collection examine Du Bois's classicism through this lens of 'Signifyin(g)', Gates's term for how African American texts produce meaning by revising other texts. Gates had originally envisioned Signifyin(g) as a uniquely African American trope, but since he acknowledges that a focus on revising one's predecessors defines any number of intertextual methodologies, it is easily compatible with our parallel interest in fuzzy connections. Signifyin $(\mathrm{g})$, then, is a kind of intertextuality, but one that is distinguished by the urgency of its political stakes. It is a tool for laying claim not only to artistic excellence or a specific authorial identity but also to humanity itself. ${ }^{16}$

\footnotetext{
${ }^{13}$ L. Hardwick, 'Fuzzy Connections: Classical Texts and Modern Poetry in English', in Tradition, Translation, Trauma: The Classic and the Modern, ed. J. Parker and T. Matthews, Oxford, 2011, p. 42.

14 Ibid., pp. 42-3. See also Greenwood, Afro-Greeks (n. 5 above), pp. 1-14.

15 H. L. Gates, Jr., The Signifying Monkey: A Theory of African-American Literary Criticism, Oxford, 1989, p. 165.

16 Gates, following Zora Neale Hurston, observes that one can Signify for love and pleasure, not only for political ends; see Gates, Signifying Monkey (n. 15 above), pp. 70 and 118. Du Bois's own view, however, at least as he expressed it in 1926, was that 'all art is propaganda, and ever must be'; see W. E. B. Du Bois, 'Criteria of Negro Art', in W. E. B. Du Bois: A Reader, ed. D. L. Lewis, New York, 1995, pp. 509-15 (514) and the contributions of Aigbedion and Lee in this collection. On intertextuality and the revision of other texts in Roman poetry, see C. Martindale, Redeeming the Text: Latin Poetry and the Hermeneutics of Reception, New York, 1993 and Hinds, Allusion and Intertext (n. 12 above), esp. pp. 17-51; on pp. 52-98 and 123-44, Hinds discusses how intertextuality serves to construct the poet's voice and to contextualize that voice in relation to other poets.
} 
As the essays in this collection show, Du Bois's classicism - his Signifyin(g) on Greece and Rome - is central to his project of demanding a place for black people in the political community and in the human community. Notably, however, Du Bois's Signifyin(g) expresses not just love for Greek and Roman culture, but also a deep resentment for the role the Classics have played in racist practices and ideologies. In this respect, Du Bois's classicism forms part of the 'Oedipal' love-hate relationship that Barbara Goff and Michael Simpson have discussed in their work on Greek tragedy among the African diaspora. They argue that authors in post-colonial contexts love the metaphorical parent that is classical culture, both on its own merits and because it is constitutive of their own works. At the same time, the Classics are an enemy that has done violence to the authors and their communities and that they are not supposed to love. ${ }^{17}$

Du Bois responds to this tension in the reception of Greek and Roman antiquity with an aggressive challenge to the view that the Classics should or could be marked as 'white' in the first place. His work thus prefigures recent discussions that call even the very term 'black classicism' into question. ${ }^{18}$ The label seems to suggest that classicism, by definition and unless it is modified by an adjective, is not black. This is a problem especially for a project like ours: by using the term 'black classicism', we risk reinforcing an exclusionary view of the Classics that Du Bois fought hard to dismantle. ${ }^{19}$ We have chosen to situate $\mathrm{Du}$ Bois within black classicism nonetheless, because he wrote deliberately and emphatically as a black American, and his rhetoric gained much of its force from this act of self-positioning. Furthermore, we have come to believe that the term offers a better characterization of Du Bois's classicism than its alternative, Classica Africana. We did adopt the latter label for the panel at the 2016 SCS annual meeting in San Francisco for which we first conceived these papers. Yet Michele Valerie Ronnick, who coined the term Classica Africana, originally defined it as a 'subfield of the classical tradition' that 'examines the undeniable impact, both positive and negative, that the GraecoRoman heritage has had on people of African descent in their creative and professional endeavors'. ${ }^{20}$ Instead of examining the impact of Greek and Roman material on Du Bois, the essays in this collection emphasize the way that Du Bois shapes and reinvents Greek and Roman antiquity for his own purposes. Furthermore, Du Bois deploys the Classics to engage with debates that extend back to the Greco-Roman world but are not exclusively rooted in it. For these reasons, we believe 'black classicism', rather than Classica Africana, better reflects Du Bois's mode of classical reception.

\footnotetext{
17 Goff and Simpson, Black Aegean (n. 5 above), especially pp. 55-66. Recent discussions of this topic include Greenwood, Afro-Greeks (n. 5 above), pp. 2-9; McConnell, Black Odysseys (n. 5 above), pp. 3-4 and 27-33; and Malamud, African Americans and the Classics (n. 5 above), pp. 3-5.

18 See, e.g., Rankine, Ulysses in Black (n. 5 above), pp. 22-34; Goff and Simpson, Black Aegean (n. 5 above); Greenwood, Afro-Greeks (n. 5 above), pp. 1-13; African Athena, ed. Orrells et al. (n. 5 above), esp. the editors' remarks on pp. 11-16 and T. Roynon's contribution on pp. 380-97; and McConnell, Black Odysseys (n. 5 above), pp. 9, 13-14.

19 See McConnell, Black Odysseys (n. 5 above), pp. 13-14 on the risks of reproducing colonialism in classical reception studies, and how scholarly self-awareness can help to 'decolonize' this research.

${ }^{20}$ Ronnick in Autobiography (n. 6 above), p. 5.
} 
Our third question relates to the geographical limits or, to put it differently, the main geographical 'target' of Du Bois's classicism. This concern emerges in particular in the appeal that concludes the passage from Souls quoted above, where Du Bois asks, 'Is this the life you grudge us, O knightly America? Is this the life you long to change into the dull red hideousness of Georgia?' Du Bois's classicism is bound up with his claims to equality as a human being, and for most of his life his efforts to realize those claims played out specifically in the United States. While Du Bois participated in Pan-African movements from the early stages of his career, and at the end of his life became a citizen of the new state of Ghana, he spent decades as an activist, scholar, and journalist devoted to the problem of race in American life. Because the intersection between Du Bois's classicism and his commitment to doing work in the world is a key theme of this collection, we focus largely on the ways in which Du Bois's engagement with the Classics speaks to an American context. In taking this approach, we do not intend to contradict the recent scholarship (discussed at the start of this introduction) that has established the diasporic nature of classical reception in black communities across the globe. Nor do we mean to elide a central tension in Du Bois's own politics, between his struggle for the rights of African Americans in the United States and his investment in Pan-African and international solidarity. ${ }^{21}$ Rather, we take Justine McConnell's point that even though there are themes that connect classical receptions across the Black Atlantic, it would be a mistake to ignore the African diaspora's heterogeneity and each author's specific place in space and time. ${ }^{22}$ In Emily Greenwood's memorable formulation, classical receptions are 'omni-local', that is, they always express and engage with the regionally specific, even and especially when they lay claim to universal significance. ${ }^{23}$ For the purposes of this collection of essays, we accordingly read Du Bois as part of a tradition of African American writers who use classical antiquity to critique American politics and American exceptionalism. ${ }^{24}$ To be sure, Du Bois's pursuit of transnational ideals also offers fruitful ground for studying and interrogating claims of the 'universal' relevance of Greek and Roman antiquity. We concentrate on the American specificity (and hence the local quality) of Du Bois's classicism, but work remains to be done on the interactions between his classicism and his cosmopolitan thought.

In these and other respects, this collection of essays puts Du Bois's writing, thought, and art at the centre of the ongoing conversation about classical receptions and black classicism. The result of our efforts will, we hope, be further studies of

\footnotetext{
21 See K. A. Appiah, Lines of Descent: W. E. B. Du Bois and the Emergence of Identity, Cambridge, MA, 2014, pp. 53-77, on the interplay of nationalism and cosmopolitanism in Du Bois's thought, especially as it informed his theories of race.

22 See McConnell, Black Odysseys (n. 5 above), esp. pp. 3-4.

23 E. Greenwood, 'Afterword: Omni-Local Classical Receptions', Classical Receptions Journal, 5, 2013, pp. 354-61.

24 See, e.g., H. V. Carby, Reconstructing Womanhood: The Emergence of the Afro-American Woman Novelist, Oxford, 1987; Rankine, Ulysses in Black (n. 5 above); M. Malamud, Ancient Rome and Modern America, Malden, MA, 2009, pp. 70-97; Roynon, Toni Morrison (n. 5 above); Malamud, African Americans and the Classics (n. 5 above); and J. L. Barnard, Empire of Ruin: Black Classicism and American Imperial Culture, Oxford, 2018.
} 
how Du Bois engaged with the Classics over his long life - spanning the ten decades from the end of Reconstruction and the advent of Jim Crow to the dawn of the Civil Rights Movement - and of how his classicism fits into wider African American and African diasporic contexts. Just as importantly, we hope to bring greater attention to how Du Bois can help us read, re-read, and appreciate Greek and Roman literature today. In recent years, nativist voices in America and Europe have increasingly proclaimed themselves to be the defenders of 'Western civilisation', but Du Bois makes it plain that the world of Greek and Roman antiquity does not belong to white supremacists, the self-styled 'alt-right'. ${ }^{25} \mathrm{He}$ demonstrates that the Classics can provide ample arguments to undercut the very same exclusionary practices for which they have been appropriated.

The following essays seek out the 'fuzzy connections' between the Classics and Du Bois's work, before and after the watershed moment in 1919 with which we began this introduction. They analyze The Souls of Black Folk (1903), The Star of Ethiopia (1910s), The Quest for the Silver Fleece (1911), Darkwater (1920), and Black Reconstruction in America (1935), among other writings of Du Bois.

The first three papers focus on Du Bois's most famous publication, The Souls of Black Folk. Mathias Hanses shows that Du Bois's impassioned arguments for college education for disenfranchised black Americans recall Cicero's defence of poetry and the liberal arts in Pro Archia Poeta. Throughout Souls, Hanses argues, Du Bois presents himself as a new Cicero and Souls as the next step in a tradition of educational philosophy that stretches back to antiquity. Yet Du Bois also reinvents this tradition for his own purposes, and he casts Cicero as his ally in the fight not only for higher learning but also for tolerance and transcendence of the colour line. Irenae Aigbedion offers a close study of the intersection of race and gender in Du Bois's rendition of the myth of At(a)lanta. Du Bois's tale, as Aigbedion demonstrates, is more deeply indebted to Ovid's Metamorphoses than previously recognized, but Du Bois's treatment of the story also allows him to assert his own role as a mythmaker. In his version, a black woman becomes a model of empowerment and of escape from backwardness, greed, and oppression for the city of Atlanta, for African Americans, and for the entire American South. Tom Hawkins places Du Bois's metaphor of the Veil in dialogue with Plato's Allegory of the Cave, following Du Bois's treatment of the image from Souls through his work in the following decades. While Du Bois never explicitly refers to Plato's Cave, Hawkins draws out the 'fuzzy connections' between these two images. The Veil is an artificial barrier between black and white Americans that, like the Cave, imprisons human beings and prevents them from true understanding. Yet while Plato's prisoners can learn to leave the Cave, Du Bois's Veil is a social construct that no individual (black or white) can ultimately escape, even when she recognizes its falsity. In Du Bois's later work, the figure of Prometheus emerges alternately as the creator of the Veil and as an embodiment of the enduring struggle against it.

\footnotetext{
${ }^{25}$ See, e.g., K. A. Appiah, 'There Is No Such Thing as Western Civilisation', The Guardian, 9 November 2016, retrieved 29 November 2016, from https://www.theguardian.com/world/2016/nov/09/westerncivilisation-appiah-reith-lecture.
} 
The next two papers explore Du Bois's engagement with the Classics in the years after Souls. Evan Lee turns to Du Bois's historical pageant, The Star of Ethiopia, which traces the history of African Americans beginning in ancient Africa. The pageant, as Lee shows, reflects Du Bois's theories of nationality, particularly his view that a shared history was essential for uniting individuals into a nation. In response to the use of Greek and Roman antiquity in European and American national mythologies, Du Bois asserts the value of the ancient past of African civilizations, and he makes classicism a key tool for articulating not only European but also African national identities. Harriet Fertik examines Du Bois's creative engagement with Aristotelian political thought in 'Of the Ruling of Men', showing how Du Bois deploys classical conceptions of democracy in order to defend a powerfully inclusive definition of citizenship. As Aristotle does in his Politics, Du Bois argues for the superiority of 'the many' compared to any select group of citizens, and his arguments for inclusive democracy build on an Aristotelian understanding of how the polity can best produce wisdom.

The collection concludes with a retrospective by Patrice Rankine, which evaluates Du Bois's place in the history of the reception, reworking, and rejection of classical themes and models in African American literature. Du Bois's classicism, as Rankine shows, is bound up with his blackness and is emblematic of a black literary style. In particular, Rankine underlines that Du Bois's deliberately open-ended use of classical texts - and of the writings of German humanists who inspired Du Bois during his time in Berlin - should be read as an instance of 'Signifyin(g)'. This analysis indicates that Du Bois's commitment to classical humanism transcends the citation (or lack thereof) of specific texts and authors. Rather, he creates a dialogue with and between the thinkers of the past and of the present, without limiting himself to specific voices or time periods.

In what follows, then, we examine not only Du Bois's engagement with classical thought and literature, but also how he understands the significance of classical reception. What does he think is at stake for those who lay claim to antiquity and make themselves its interpreters? ${ }^{26}$ The Du Bois we see in these essays is always attuned to the political uses of the Classics, yet he looks to antiquity not merely for ideals to imitate, but for questions to debate, and for habits of thought that compel us to recognize and reconsider our assumptions about the present. We hope to show that Du Bois's agile and daring approach to the past offers a powerful model for scholars of reception studies today.

Acknowledgements We would like to thank Stephen M. Wheeler for his support from the very beginning of this project; the audience at the 2016 meeting of the Society for Classical Studies who joined us to discuss the first versions of these essays; and Daniel Orrells and Katherine Harloe for their encouragement and guidance. The anonymous reviewers for the journal gave us thoughtful comments that enriched and strengthened this collection (and the introductory essay in particular). Finally, we are especially grateful to the contributors-Irenae Aigbedion, Tom Hawkins, Evan Lee, and Patrice Rankine-from whom we have learned much, and whose dedication made this project possible.

\footnotetext{
${ }^{26}$ See L. Hardwick, Reception Studies, Cambridge, 2003, p. 11: 'Reception is and always has been a field for the practice and study of contest about values and their relationship to knowledge and power'.
} 